\title{
Use of Education Information Network on Mathematics Achievements of Secondary School Students: The Teachers' Views
}

\author{
Salih SARIŞIK ${ }^{1}$, Sevilay SARIŞIK ${ }^{2}$, Cemal YAMAK ${ }^{3}$, Mustafa GÜNGÖR ${ }^{4}$
}

\section{ARTICLE INFO}

\section{Article History:}

Received

01.02.2021

Received in revised form

30.08.2021

Accepted

01.12.2021

Available online

01.01.2022

\begin{abstract}
The main aim of the research is to determine teachers' opinions on the impact of the Education Information Network, which is continuously updated and developed, on the success of studentds' entering high school entrance exam in Turkey by means of necessary studies. Case study which is one of the qualitative research methods, was used in the study. The study group of the research consists of 25 mathematics teachers teaching mathematics in the 8th grade of secondary schools affiliated to the Ministry of Education in Sakarya province in the 2019-2020 academic year. Semistructured interview technique, one of the qualitative research methods, was used in the study. In the research, as a data collection tool, "semi-structured interview form" developed by the researcher was used. In order to determine whether the questions in the interview form were suitable for the purpose of the interview or not, expert opinion was consulted. Necessary corrections were made in line with the suggestions and criticisms of the experts. Due to the pandemic process involved, the interviews with the teachers in the study were made via e-mail and the data obtained were analyzed by descriptive analysis method. In line with the findings obtained from the research data, the teachers stated that the acquisitions were positive, the course content provided for the high school entrance exam was sufficient, and the evaluation process was sufficient but insecure. Ensuring active participation of students in the course, adding content suitable for individual differences, eliminating technical deficiencies, eliminating inequality of opportunity, developing and improving in terms of content and materials were suggested by the participants.
\end{abstract}

(C) IJERE. All rights reserved

Key words:

Education information network, secondary school, maths, high school entrance exam

\section{INTRODUCTION}

Information is constantly changing with the development of technology. The changes in e-platforms, the internet, tablets, computers and other devices show a movement which is accelerated rapidly. Individuals can access information at any time using these tools, make scans, conduct research, download information and discover new ideas by examining the information obtained within seconds as a result of their research (Clark \& Mayer, 2008; Salman, 2013). The changes in knowledge across the world primarily affect the institutions which provide education. The effective use of technology by individuals is one of the goals of educational institutions. In order to achieve this goal, new projects are continuously being produced. For example, The Movement for Increasing Opportunities and Improving Technology has been established in order to promote activities such as following the developments in technology by individuals and presenting subjects in the curriculum via technology. With such studies implemented within the scope of this project, it has been observed that teachers, students and educational administrators are quite effective in the education and training process (Özdemir \& Akran, 2018). One of the e-learning platforms which has an important place in these projects is the education information network. Educational platforms such as the education information network provide individuals with a variety of learning/teaching environments (MEB, 2016; Tüysüz \& Çümen, 2016). By offering a different evaluation, the education information network enables students to understand topics better by solving their questions about the course contents, to watch various media and to benefit from the electronic resources which they download to their computers. The opportunities provided by the education information network enable students to prepare for the LGS exam more effectively and make it easier for them to achieve their future goals. In order for this to happen, in addition to memorizing information, students must constantly question and reconcile the information using technological tools and determine the learning option most suitable for their own particular learning method (MEB, 2016). It can be said that individual students will be more successful in lessons and exams by

1 Ministry of Education, slh040@gmail.com, orcid org/0000-0002-6506-2830

2 Ministry of Education, sevilaykoluman@gmail.com, orcid.org/0000-0001-6750-4949

3 Ministry of Education, cemalyamak61@hotmail.com, orcid.org/0000-0002-8389-2192

4 Ministry of Education, guen_goer@hotmail.com, orcid.org/0000-0001-7762-9112 
establishing a more effective connection with the teacher, who determines the most appropriate option and method of studying for them (MEB, 2016). Teachers and students can use the education information network in a different environment from the conventional learning environment. When studies in the literature are examined, it can be seen that students benefit from the educational information network; it has been stated that it provides many opportunities such as enabling teaching by providing tangible information, supporting teaching, ensuring full learning, repeating parts which have not been understood, solving tests and setting e-exams (Türker \& Güven, 2016).

In the literature, it is seen that the number of studies of mathematics teaching over the education information network has been increasing recently. Açıgöz (2018) found that the achievement level on the mathematics course supported by the education information network on 'Different Aspects of Objects' for middle-school students was positively affected and that the students who attended the course had positive opinions about the way that the education information network supported mathematics teaching. Özbey and Koparan (2019) similarly found that mathematic teaching supported by the education informatics network was effective on 'Linear Equations and Slope' with middle-school students and Akbaş (2019) identified a positive effect on the cognitive gains of students about 'Fractions'. Vahit (2019) found that the education informatics network had a positive effect on 'Natural Numbers and Operations with Natural Numbers' and on students' achievements and attitudes towards the lesson, but not on their approach to technology. Tekin (2019) reported that the network had a positive effect on students' mathematics in 'Ratio and Proportion', but not on their metacognitive behaviour. Ankay (2019), however, found that the education informatics network supported mathematics teaching but did not have a positive effect on 'Addition and Subtraction Operations with Fractions', or on students' mathematics course achievement and attitudes towards the lesson.

Contrary to the studies briefly described above, the issue which makes this study necessary is that there has been an increase in the need for the education informatics network as a consequence of the effect of the Covid-19 pandemic affecting the whole world (Aslan, 2020). The Covid-19 virus, which is said to have spread from Wuhan in China to the whole world, caused the closure of schools in some countries and in these countries, education had to be delivered by distance education. İşman (2011) described distance education as a visual and auditory interaction between teachers and students who are very far apart. Because of the pandemic, from March 2020 the education information network has contributed significantly to the broadcast system through the e-learning environment in Turkey and to education in schools affiliated to the Ministry of Education, which has taken an effective role in maintaining teaching through distance education (Çiftçi \& Aydin, 2020).

This study examines the Covid-19 epidemic and the education information network platform together. In the first instance, a series of measures were taken in Turkey when state education in schools had to be suspended for an unpredictable period. Data from the Ministry of National Education show that 1,472,088 students who attended the high school entrance exam sessions on 20 June 2020 were affected by the pandemic closures (MEB, 2020). In order not to reduce the motivation of the 8th grade students who were to take the entrance exam to high schools during the pandemic closures and to ensure that they did not lose any of their education, secondary school 8th grade education has been continued by the distance education system as it has in all education levels.

The education informatics network, which enables teachers and students to be in mutual communication, was introduced in Turkey eight years ago in distance education, and it quickly began to be implemented and actively used at all educational levels. Over time, improvements have been made to the internet infrastructure so that students and teachers do not experience any problems in access. It is planned that distance education will be realized interactively using the education information network television channels and the Live Lesson application with computers and mobile communication tools. Because of the pandemic, in March 2020, the TRT education information network TV Secondary School channel started to deliver distance education by broadcasting on the 8th grade television.

\section{Problem Statement}

Does the use of the education information network affect the academic success of middle-school 8thgrade students in mathematics while preparing for the High School Entrance Exam? 


\section{Purpose of the Research}

The main aim of the research is to determine teachers' opinions on the impact of the education information network, which is continuously being updated and developed, on the success of students in the high school entrance exam in Turkey by means of necessary studies.

\section{The Importance of Research}

In this study, the aim is to determine the opinions of 8 th-grade mathematics teachers who guide students during the preparation process for the high school entrance exam. The study will therefore involve mathematics teachers working in the system, which makes the study unique.

It is intended that the findings of the study will play an active role in the use of the education information network for preparing for the entrance exam to high schools and that it will consequently become widespread. The findings will enable the technical staff of the education information network platform to achieve significant results and significant benefits will be provided to the development and usage of the education information network in the preparation for the high school entrance exam.

The point of view of teachers is important as it sets an example fof the use of the content of mathematics in the education information network as supplementary material and activities in lessons. This is an up-to-date and original study in terms of the use of mathematical content in the education information network and an important addition to the limited number of studies on the subject. In addition, it is functional in terms of the contributions which the findings will make and the solution suggestions which they will offer, and it will also shed light on directions for future studies in this field.

\section{METHOD}

In the study, semi-structured interview technique, one of the qualitative research methods (Yıldırım and Şimşek, 2008), was used. This technique defined as a qualitative research method enables participants to express their personal experiences, perspective, and thoughts on a subject.

\section{Data Collection Tool}

The interview form was used as a data collection tool in the study. During the preparation phase of the interview questions, the literature was reviewed and 5 open-ended questions that would express the relevant sub-problems in the best way were prepared by the researcher and written into the interview form. Open-ended research questions "provide the researcher with the opportunity to handle the phenomenon she wants to examine with a flexible and open-ended approach" (Yıldırım \& Şimşek, 2008).

In the research, the interview form has been developed to determine the teachers' opinions about the effect of using the Education Information Network in the Mathematics lesson while preparing for the High School Entrance Exam. Moreover, gender, age, the working year, and educational status were taken into consideration. It was finalized in line with the expert opinions. There are five open-ended questions in the interview form.

\section{Data Analyses}

The data obtained from the interviews have been analyzed by the descriptive analysis method. Descriptive analysis method, a determined framework consists of steps such as transferring data to this framework, determining and interpreting the findings (Yıldırım \& Şimşek, 2008). For the analysis of the data, the thematic framework has been identified by the researcher and within this scope, the data given by each researcher have been codified, and the common themes have been determined and codified by comparing the combined data.

The written texts formed as a result of the interviews were repeatedly examined, the data suitable for the purpose of the study were codified, and the themes that explain the encoded data at a general level were determined. The findings obtained are organized in tables. The teachers interviewed were coded starting from T1 to T25. In the interpretation of the findings, the opinions of the participants were included by quoting directly. 


\section{FINDINGS}

This section includes the findings of the research.

Findings regarding the problem statement

Various findings were obtained in line with the opinions of the participants regarding the effect of using the Education Information Network in the mathematics lesson on the academic achievement of middle school 8th grade students during the preparation process for the High School Entrance Exam. These findings; The education information network has a positive effect on the realization of the achievements of the mathematics curriculum in preparing for the entrance exam for high schools, the content of the mathematics lesson in the system is sufficient in preparing for the exam, the learning-teaching dimension for the math lesson positively affects the exam preparation, and the math lesson evaluations are sufficient in preparing for the exam.

\section{Findings related to sub-problems}

Findings related to 5 sub-problems determined for the effect of using education information network in mathematics during the preparation process for the entrance exam for high schools are explained below.

Findings about the effect of Education Information Network on the achievements of the 8th Grade Mathematics course curriculum on the High School Entrance Exam preparation.

Teachers' views on the effect of Education Information Network on the achievements of the 8th Grade Mathematics lesson curriculum on the High School Entrance Exam preparation are presented below.

Table 1

Teachers' opinions on the effect of Education Information Network on the achievements of the 8th Grade Mathematics course curriculum on the High School Entrance Exam.

\begin{tabular}{clcc}
\hline Theme (Categories) & Codes & N & \% \\
\hline $\begin{array}{c}\text { The effect of realization } \\
\text { of mathematics course }\end{array}$ & Positive (T1,T2,T11,T12,T13,T17,T20,T21,T22,T24) & 10 & 40 \\
achievements on exam & Enough (T3,T8,T9,T10,T11,T19) & 6 & 24 \\
preparation & Not enough (T4,T5,T6,T16,T18) & 5 & 20 \\
& Not like face to face training (T14,T15,T23) & 3 & 12 \\
& Negative (T25) & 1 & 4 \\
\hline
\end{tabular}

When Table 1 is examined, it is seen that the opinions of the teachers about the effect of the Education Information Network on the achievement of the 8th grade mathematics curriculum on the preparation for the high school exam are mostly positive at a rate of $40 \%$. Other opinions are, in turn, $24 \%$ sufficient, $20 \%$ not sufficient, $12 \%$ not like face-to-face training and $4 \%$ negative. The exact quotations taken from the opinions of the teachers are presented below.

- "I think it has a very positive effect on students who work regularly and take tests." (T1)

- "I think the gains are given on time and I find it sufficient." (T3)

- "I do not think there is any problem in training the gains, but I think it is insufficient in terms of exams. "(T16)

- "I do not think it is as much as face-to-face education, but it is not a problem in terms of training gains in education under these conditions. "(T15)

- "I don't think it has an impact on the entrance exam to high schools. "(T25)

Findings about the effect of the content dimension of the 8th Grade Mathematics course curriculum of the Education Information Network on the preparation for the high school entrance exam.

Teachers' views on the effect of the content dimension of the Education Information Network's 8th Grade Mathematics course curriculum on the preparation for the high school entrance exam are presented below.

Table 2

Teachers' views on the effect of the content dimension of the Education Information Network's 8th Grade Mathematics course curriculum on preparation for the entrance exam for high schools. 


\begin{tabular}{clcc}
\hline Theme (Categories) & Codes & $\mathbf{N}$ & $\mathbf{\%}$ \\
\hline $\begin{array}{c}\text { The effect of the contents } \\
\text { of the mathematics course on } \\
\begin{array}{c}\text { the preparation for the } \\
\text { entrance exam to high schools }\end{array}\end{array}$ & Enough (T4,T8,T9,T10,T11,T12,T13,T17,T18,T19,T20,T21,T22,T23,T24) & 15 & 60 \\
Nonough (T1,T2,T3,T5,T14,T16,T25) & 7 & 28 \\
2 & 5 & 20 \\
\hline
\end{tabular}

When Table 2 is examined, it is seen that the opinions of the teachers about the effect of the content dimension of the 8th grade mathematics lesson curriculum of the Education Informatics Network on the preparation for the entrance exam to high schools are sufficient at the rate of $60 \%$. Other views are, in turn, $28 \%$ is not enough and should be improved by $20 \%$. The exact quotations taken from the opinions of the teachers are presented below.

- $\quad$ "I think the 8th grade contents in the system are sufficient." (T8)

- " "There are situations where it is insufficient, the question contents are further diversified." (T14)

- "I think the content should be enriched in preparation for the high school entrance exam." (T7)

Findings on the effect of the learning - teaching dimension of the Education Information Network's 8th Grade Mathematics course curriculum on the preparation for the high school entrance exam.

Teachers' opinions on the effect of the learning - teaching dimension of the Education Information Network's 8th Grade Mathematics course curriculum during the preparation process for the high school preparation exam are presented below.

Table 3

Teachers' opinions on the effect of the learning - teaching dimension of the Education Information Network's 8th Grade Mathematics lesson curriculum on the preparation for the High Schools.

\begin{tabular}{clll}
\hline Theme (Categories) & Codes & N & $\%$ \\
\hline Mathematics lesson & Positive (T1,T2,T3,T4,T5,T7,T8,T16,T17,T18,T22,T24) & 12 & 48 \\
learning-teaching activities the & Useful and fun (T11,T12,T13,T20,T21,T3) & 6 & 24 \\
effect on preparation for high & Enough (T6,T9,T15,T19) & 4 & 16 \\
school entrance exams & Not enough (T14,T25) & 2 & 8 \\
& Striking (T10) & 1 & 4 \\
\hline
\end{tabular}

When Table 3 is examined, it is seen that the opinions of the teachers about the effect of the learning teaching dimension of the 8th grade mathematics lesson curriculum of the Education Information Network during the preparation process for the high school entrance exam are positive at the rate of $48 \%$. Other opinions were, in turn, useful and entertaining at $24 \%$, adequate at $16 \%$, not enough at $8 \%$ and remarkable at $4 \%$. The exact quotations taken from the opinions of the teachers are presented below.

- " "I think it has a positive effect on academic success." (T1)

- " I think that the learning environment is fun and beneficial and positively affects the students." (T11)

- " "I think the methods and techniques used, visuals and media are sufficient." (T6)

- " "It is insufficient to detect the deficiencies of the students and takes a lot of time." (T14)

- "I think the methods and techniques used attract the attention of the students and thus the lesson is efficient." (T10)

Findings about the effect of the evaluation dimension of the Education Information Network's 8th Grade Mathematics course curriculum on the preparation for the high school entrance exam.

Teachers' opinions about the effect of the evaluation dimension of the Education Information Network's 8th Grade Mathematics curriculum during the preparation process for the entrance exam to high schools are presented below.

\section{Table 4}

Teachers' views on the effect of the evaluation dimension of the Education Information Network's 8th Grade Mathematics course curriculum on preparation for the High Schools entrance exam. 


\begin{tabular}{clcc}
\hline Theme (Categories) & Codes & N & \% \\
\hline Evaluating a math & Enough (T1,T3,T4,T7,T13,T16,T19,T20,T21,T22,T23) & 11 & 44 \\
lesson activities the effect on \\
$\begin{array}{c}\text { preparation for high school } \\
\text { entrance exams }\end{array}$ & Not enough (T2,T5,T9,T14,T17,T18,T24) & 7 & 28 \\
& Not safe (T8,T11,T12,T15,T16) & 5 & 20 \\
& Not suitable for the exam (T9,T12,T24,T25) & 4 & 16 \\
\hline
\end{tabular}

When Table 4 is examined, it is seen that the opinions of the teachers about the effect of the evaluation dimension of the 8th grade mathematics lesson curriculum of the Education Information Network on the preparation for the entrance exam to high schools are sufficient at the rate of $44 \%$. Other opinions are, in turn, $28 \%$ is not enough, $20 \%$ is not reliable, $16 \%$ is not suitable for LGS level, and it provides $12 \%$ advantage. The exact quotations taken from the opinions of the teachers are presented below.

- " I think it is sufficient in terms of gain assessment." (T3)

- "The assessment dimension is not sufficient in terms of high school entrance exam." (T5)

- "I do not find it safe for students to try themselves in preparation for the high school entrance exam. Face-to-face trial exams at school give more realistic results." (T8)

- "I find it a little insufficient in the evaluation part because the questions and tests are usually prepared at a medium and simple level." (T9)

- "In the evaluation part, the immediate feedback is important for the student to determine her own situation and plan accordingly." (T22)

\section{Findings regarding the use and development of the Education Information Network application.}

Teachers' opinions on the use and development of the Education Information Network application are presented below.

Table 5

Teachers' opinions on the use and development of the Education Information Network application.

\begin{tabular}{clll}
\hline Tema (Kategoriler) & Kodlar & N & $\%$ \\
\hline & Content development and enrichment (T5,T9,T10,T12,T13,T14,T15,T16,T17,T20,T24) & 11 & 44 \\
Education & Students should be encouraged (T1,T3,T5,T7,T8,T9,T15,T16,T17,T19,T21) & 11 & 44 \\
Information Network For & Students should be provided with the necessary facilities (T2,T9,T11,T14,T18,T22) & 6 & 24 \\
use and development & Students should continue to attend (T4,T8,T12,T19,T21) & 5 & 20 \\
Opinions and suggestions & Technical deficiencies should be eliminated (T7,T20) & 2 & 8 \\
& Content should be prepared by professionals (T8,T25) & 2 & 8 \\
& Individualized special students should be included (T6) & 4 & 4 \\
& Students should be educated about the use of technology (T23) & 1 & 4 \\
\hline
\end{tabular}

When Table 5 is examined, it is seen that the opinions of teachers about the use and development of the Education Informatics Network application are at most $44 \%$ as content should be developed and enriched and students should be encouraged. Other opinions are, respectively, $24 \%$ of students should be provided with the necessary facilities, $20 \%$ should be provided with students' attendance, $8 \%$ should be eliminated and the content should be prepared by professional people, $4 \%$ should be provided with individualized special students and students should be educated about the use of technology. The exact quotations taken from the opinions of the teachers are presented below.

- "Students should be encouraged and the content should be developed at the level of the entrance examination for high schools. "(T5)

- " "Students should be guided and content questions developed." (T15)

- "Most of the students participate, but I think that the necessary opportunities should be provided to the students who do not have the means." (T2)

- "Students' participation should be ensured and followed up. Continuous enrichment of content." (T12)

- " "Should technical problems be fixed and the system enriched." (T20)

- "Lectures can be made more professionally. Support can be obtained from the organizations that do this job." (T25)

- " "Students should be supported and computer usage education should be given." (T23) 


\section{RESULT AND DISCUSSION}

The results of this study conducted on the effect of the use of educational information network in mathematics on the academic success of middle-school 8th grade students while preparing for the high school entrance exam, and the results of the review of the literature are as follows.

The results of the education information network's effect on preparation for the entrance exam for high schools in the realization of the achievements of students taking the 8th grade mathematics course curriculum

The opinions of the mathematics teachers participating in the study showed that they realized that the achievements of maths in the 8th-grade has a positive effect when preparing for the exam, and that the achievements regarding exam questions are at a sufficient level.

Eryılmaz and Salman (2014) found that the use of education information networks in lessons facilitates both the teaching process and the outcomes. Fidan et al. (2016) stated that when the examples found in the educational information network are used by teachers, students' attitudes towards the lesson change in a positive way, and their active participation in the lesson increases. The findings of the current study confirm those findings.

Results regarding the effect of the contents of the 8th grade mathematics course curriculum on the education information network on preparation for the high school entrance exam

The opinions of the maths teachers participating in the study showed that the content of maths for the 8thgrade is sufficient to prepare for the exam.

It has been stated that the media and visual activities in the educational informatics network provide an advantage for students' permanent learning (Murphy, 2016). Ring (2001) found that the web-based learning contents which she developed were effective, accessible and beneficial for individuals' learning. Özkan and Deniz (2014), however, found that the contents in the system were not sufficient for preparing for the exam. Although Bozkuş and Karacabey (2019) found that the content of the education information network was insufficient for the exam, the teachers in the current study reported that the course content of the education information network is sufficient. Yerli (2018) stated that the education information network has the same effect on the academic success of students as the lessons taught in class with textbooks prepared in the traditional way.

The results regarding the effect of the learning/teaching dimension of the education information network's 8th grade mathematics course curriculum on preparation for the entrance exam to high schools.

The opinions of the mathematics teachers participating in the study showed that the learning/teaching activities of the 8th-grade mathematics lesson in the system have a positive and beneficial effect on preparing for the exam.

Tüysüz and Çümen (2016) reported that students found the education information network useful for repeating lessons, completing the necessary acquisitions and preparing for the exams. Kurıc1, Artun and Bakırc1 (2018) stated that the education information network supported teaching methods and had a positive effect on students' learning. Çetin and Günay (2011) found that web-based studies made students happier, and Uluçay and Çakır (2014) stated that web-based activities positively affected students' attitudes towards the course. The current findings support those of these previous studies. In other words, it was observed that the education information network and the learning environment affect students' success in mathematics in preparing for the exam.

Results regarding the effect of the evaluation dimension of the education information network's 8th grade mathematics course curriculum on preparation for the entrance exam to high schools

The opinions of the mathematics teachers participating in the study showed that the evaluation element in the 8 th grade mathematics course in the system is at a sufficient level for preparing for the exam.

Ümre (2010) found that maths questions asked in mock exams and in the entrance exams to high schools at the end of the year help to control the cognitive thinking of students. In other words, both face-to-face and e- 
assessment applications performed in the school environment through the educational information network have an important role in students' preparation for the exam (Güler \& Yakar, 2011). The most important of these skills is problem solving. In the current study, the participating teachers stated that the questions in the education information network evaluation part developed the problem-solving skills of the students and that these skills were used in the high school entrance exam. Students try to solve the assessment tests in the education information network, ask their teachers about the tests which they cannot solve, and develop a different perspective. Students who approach mathematics questions from this perspective can use their experience effectively in exams such as high school entrance exams and can adjust the duration of the exam to be more efficient.

\section{Results regarding the use and development of the education information network}

The participating mathematics teachers emphasized that the key part of the network is improving and enriching the contents. They stated that the content of the entrance exam to high schools on the education information network system should be improved and enriched, and also believed that the evaluation section of the network is inadequate.

Altin (2014) reported that the content of the education information network system is incomplete in terms of preparing students for the exam. Pamuk (2013) asked participant teachers about their opinions on the use of educational information networks in teaching mathematics and they answered that updating the content part of the mathematics lesson in their system would make teaching more enjoyable. Altn (2014) found that the EBA training platform is beneficial, but that the content part is insufficient in terms of the exam and that it must be constantly renewed and increased: the current study made a similar finding.

As a result, the educational informatics network, an e-learning platform which teachers and students use effectively almost every day, has a structure which develops day by day and is enriched in terms of content, making great contributions to distance education during the Covid-19 pandemic. Even so, it is not considered sufficient by the teachers during this period, and it is not as effective as expected by the students in terms of preparation for the entrance exam for high schools. Especially in terms of preparation for the exam, it cannot meet the needs of the students regarding the content at the expected level. Future studies including both teachers and students, who are the most important factors in the education process, and the pandemic period which we are currently in, will be effective in the faster development and updating of the education information network.

\section{SUGGESTIONS}

\section{Recommendations based on the results}

Based on the results obtained from the research, the following suggestions are made to raise the effect of mathematics teaching on academic achievement to the expected level when preparing for the entrance exam for high schools with the education information network system.

- The education information network needs to be developed more in terms of content.

- Technical training can be given to relevant employees who can produce content based on courses to redress the lack of content in the education information network.

- It is very important for the Ministry of National Education to provide teachers with in-service training opportunities related to content development and to include teachers in this process, in order to reach the desired level in terms of content.

- It is very important to solve the technical and infrastructure problems experienced by students, and many students need technological materials. Appropriate solutions should be found for these problems, and an increase in usage rate and academic success will be achieved as a consequence.

- Students' active use of the educational information network can be monitored and supervised by their teachers.

\section{Recommendations for future research}

- It should be ensured in future studies that different problem areas can be identified by expanding the interview form used in this research which contained only five questions.

- The analysis of the study group should be expanded to different geographical regions of Turkey. 
- In this study, it was found that the EBA contents are insufficient. Future studies should investigate the reasons for this in detail.

- In this study, only mathematics teachers were recruited as a study group. In similar future studies, parents and students could be included in the study group.

\section{REFERENCES}

Açıkgöz, G. (2018). Ĕ̆itim bilişim ă̆ı (EBA) destekli matematik öğretiminin 7. sınıf öğrencilerinin akademik başarısına etkisi (Yayımlanmamış yüksek lisans tezi). Kastamonu Üniversitesi, Fen Bilimleri Enstitüsü, Kastamonu.

Alkan, C. (2011). Ĕğitim teknolojisi. Ankara: Anı Yayıncılık.

Altın, H. M. (2014). Öğrenci, öğretmen, yönetici ve veli bakış açısıyla fatih projesinin incelenmesi (Yüksek lisans tezi). Başkent Üniversitesi Eğitim Bilimleri Enstitüsü, Ankara.

Altun, M. (2010). Ĕ̆gitim fakülteleri ve sımı öğretmenleri için matematik öğretimi. Ankara: Alfa Aktüel Yayıncılık.

Ankay, E. (2019). 5e öğretim modeline dayalı eğitim bilişim ă̆ı (EBA) kullanımının 5. sınıf öğrencilerinin kesirlerle toplama ve çıkarma işlemleri konusundaki başarısına, tutumuna ve bilgilerinin kalııllğı̆na etkisi (Yayımlanmamış yüksek lisans tezi). Gazi Üniversitesi, Eğitim Bilimler Enstitüsü, Ankara.

Aslan, R. (2020). Tarihten günümüze epidemiler, pandemiler ve Covid-19. Ayrıntı Dergisi, 8(65), 35-41.

Aydınözü, D., Sözcü, U. \& Akbaş, V. (2016). Coğrafya öğretiminde eba içeriklerinin öğrenci başarısına etkisi. Karadeniz Sosyal Bilimler Dergisi, 8(15), 339- 357.

Bilici, A. (2011). Öğretmenlerin bilişim teknolojileri cihazlarının eğitsel bağlamda kullanımına ve eğitimde fatih projesine yönelik görüşleri: sincan il genel meclisi i.ö.o. örneğgi. 5th International Computer \& Instructional Technologies Symposium'da sunulmuş bildiri, Fırat Üniversitesi, Elazı̆̆.

Birinci, A. G. D. K. (2014). Merkezi sistem ortak sinavlarında ilk deneyim: matematik dersi. Journal of Research in Education and Teaching [Ĕ̆itim ve Öğretim Araştırmaları Dergisi], 3(2), 8-16.

Bozkuş, K. \& Karacabey, K. B. (2019). Fatih projesi ile eğitimde bilişim teknolojilerinin kullanımı: ne kadar yol alındı? Yaşadıkça Eğitim, 33(1), 17-32.

Clark, R.C. \& Mayer, R.E. (2008). E-learning and the science of instruction (2nd ed.). San Francisco:JosseyBass/Pfeiffer

Çakmak, Z. \& Taşkıran, C. (2017). Sosyal bilgiler öğretmenlerinin perspektifinden eğitim bilişim ağı (eba) platformu. Uluslararası Türk Eğitim Bilimleri Dergisi, 5(9), 284-295.

Çavuş, H. (2002). Internet tabanlı uzaktan eğitime pratik bir yaklaşım (Yayımlanmamış yüksek lisans tezi). Yüzüncü Yıl Üniversitesi, Van.

Çavuş, H. (2006). Türkiye'de matematik öğretiminde öğretmenlerin eğitim ortamlarında bilgisayar ve matematik programlarından yararlanma düzeyleri (Yayımlanmamış doktora tez). Yüzüncü Yıl Üniversitesi, Van.

Çetin, E. (2020). Eba ders ile coğrafya öğretiminin öğrencilerin akademik başarısına etkisi (Yüksek lisans tezi). Dokuz Eylül Üniversitesi, Eğitim Bilimleri Enstitüsü.

Çetin, O. \& Günay, Y. (2011). Fen eğitimine yönelik örnek bir web tabanlı öğretim materyalinin hazırlanması ve bu materyalin öğretmen öğrenci görüşleri doğrultusunda değerlendirilmesi. Ahi Evran Üniversitesi Ĕ̆itim Fakültesi Dergisi, 12(2), 175-202.

Çınar, O. (2006). İlköğretim okulu öğretmen ve yöneticilerinin yapılandırmacı eğitim yaklaşımı ve programı hakkındaki görüşleri. Ĕ̆itim Fakültesi Dergisi, 7, 11, 47-64.

Çiftçi, B. \& Aydın, A. (2020). Eğitim bilişim ağı (EBA) platformu hakkında fen bilimleri öğretmenlerinin görüşleri. Türkiye Kimya Derneği Dergisi. 5, (2), 111-130.

Demirel, Ö. (2011). Eğitimde program geliştirme. Ankara: Pegem Akademi Yayınları.

Duncan, C. (2001). Why digital repositories? (Darft). 12 May1s 2003 tarihinde http://www.intrallect.com/papers/why_digital_repositories.pdf adresinden erişildi. 
Eğitim Reformu Girişimi [ERG]. (2017). Eğitim zleme aporu 2016-2017, ERG, İstanbul. http://www.egitimreformugirisimi.org/egitim-izleme-raporu-2016-

Ekici, M., Arslan, İ. \& Tüzün, H. (2016). Eğitim teknolojileri okumaları. Eğitim bilişim ağı (EBA) web portalı kullanılabilirlĭğinin göz izleme yöntemiyle değerlendirilmesi, 2 3-297, Ankara: TOJET.

Erensayın, E. \& Güler, Ç. (2016). Eba platformundaki ders materyallerinin eğitsel yazılım değerlendirme ölçütlerine göre değerlendirilmesi. Ahi Evran Üniversitesi Kırşehir Eğitim Fakültesi Dergisi, 18(1), 657678.

Ertem-Akbaş, E. (2019). Eğitim bilişim ağı (EBA) destekli matematik öğretiminin 5. sınıf kesir konusunda öğrenci başarılarına etkisi. Journal of Computer and Education Research, 7(13), 120-145.

Ertürk, S. (1982). Eğitimde program geliştirme (4. Baskı). Ankara: Meteksan.

Eryılmaz, S. \& Salman, Ş. (2014). FATİH Projesi kapsamında yer alan öğretmen ve öğrencilerin projeden beklentileri ve bilişim teknolojileri kullanımına karşı algıları. Electronic Journal Of Occupational Improvement And Research, 2(1), 46-63.

Fidan, K. N., Erbasan, Ö. \& Kolsuz, S. (2016). Sınıf öğretmenlerinin eğitim bilişim ağından (EBA) yararlanmaya ilişkin görüşleri, Uluslararası Sosyal Araştırmalar Dergisi, 9(45), 626-637.

Güler, Z. (2010). İlköğretim öğrencilerinin SBS puanları ile ders başarıları, bilimsel süreç becerileri ve mantıksal düşünme yetenekleri arasındaki ilişki. (Yayınlanmamış yüksek lisans tezi). Abant İzzet Baysal Üniversitesi Sosyal Bilimler Enstitüsü, Bolu.

İşman, A. (2011). Uzaktan eğitim. Ankara: Pegem Akademi.

Lee, H. (2008). Students' perceptions of peer and self assessment in a higher online knowledge sharing. Education Tech Research Dev., 55, 573-595.

Karademirci, A.H. (2010). Öğretim teknolojileri: Tanımı ve tarihsel gelişimine yeniden bakmak. Akademik Bilişim Konferansı, 10-12 Şubat, Muğla, Türkiye.

Karaman, S. (2005). Öğrenme nesnelerine dayalı bir içerik geliştirme sisteminin hazırlanması ve öğretmen adaylarının nesne yaklaşımı ile içerik geliştirme profillerinin belirlenmesi (Doktora tezi). Sosyal Bilimler Enstitüsü., Atatürk Üniversitesi.

Karaman, S., Özen, Ü. \& Yıldırım, S. (2006). AtaNesA nesne ambarının yapısı ve işleyişi. Eğitim ve Bilim Dergisi, 31(140), 34-42.

Kazan, H., Karaman, E., Akçalı, B. Y. \& Şişmanoğlu, E. (2015). Assessment of teog examination success: topsis multi-criteria decision-making method practice. Procedia-Social and Behavioral Sciences, 195, 915-924.

Keser, H. (1988). Eğitimde nitelik geliştirmede BDE ve ders yazılımların rolü. Eğitimde Arayışlar 1. Sempozyumu'nda Sunulan Bildiri Metinleri, 13-14 Nisan 1991, Kültür Koleji, İstanbul, Türkiye.

Koç Akran, S. \& Özdemir, E. (2018). Eğitim bilişim ağı (EBA) ders modülünde yer alan sorular ile TEOG sınavında çıkan soruların ilişkisine yönelik öğretmen görüşleri. Harran Maarif Dergisi, 3 (2), 14-26.

Kırıcı, M. G., Artun, H. \& Bakırcı, H. (2018). Eğitim bilişim ağı destekli eğitimin "kuvvetin ölçülmesi ve sürtünme" kavramlarının öğrenilmesine etkisi. Turkish Studies, 13(6), 23-38.

Kurtdede Fidan, N., Erbasan, Ö. \& Kolsuz, S. (2016). Sınıf öğretmenlerinin Eğitim bilişim ağı'ndan (EBA) yararlanmaya ilişkin görüşleri. Uluslararası Sosyal Araştırmalar Dergisi, 9(45), 626-637.

Kurtoğlu, M. \& Seferoğlu, S. S. (2012, Ekim). Bilgisayar ve öğretim teknolojileri eğitimi (böte) bölümü öğrencilerinin geleceğe yönelik bakış açıları üzerine bir inceleme. 6. Uluslararası Bilgisayar ve Öğretim Teknolojileri Sempozyumu'nda sunulan bildiri, Gaziantep Üniversitesi, Gaziantep

Mahadevan, S. (2002). A learning object model for electronic learning. Virginia Polytechnic Institute and State University: Unpublished postgraduate thesis.

Milli Eğitim Bakanlığı (2009). Ilköğretim matematik dersi 6-8. sınıflar öğretim programı ve klavuzu. Milli Basım Evi. 
Milli Eğitim Bakanlığı (2012). FATïH projesi web sayfası. http://fatihprojesi.meb.gov.tr/

Milli Eğitim Bakanlığ1 (2013). Millî eğitim bakanlı̆̆l ortaöğretim kurumlarına geçiş yönergesi. http://mevzuat.meb.gov.tr/html/ortaogryonerge\%5Cortogryon_1.html

Milli Eğitim Bakanlığı (2013). Millî eğitim bakanlığı ortaöğretim kurumlarına geçiş yönergesi. http://www.oges.meb.gov.tr/

Milli Eğitim Bakanlığı (2016). EBA hakkında. (http://www.eba.gov.tr/hakkında/tam;

Milli Eğitim Bakanlığı (2017). Liselere geçiş sınavı. http://www.meb.gov.tr/bakan-yilmaz-aa-editormasasindaortaogretime-geciste-Mevcut uygulamayiacikladi/haber/ 14882 /tr

Milli Eğitim Bakanlığ1 (2019). Sinavla öğrenci alacak ortaöğretim kurumlarına ilişkin merkezî sınav başvuru ve uygulama kilavuzu. http://mevzuat.meb.gov.tr/dosyalar/2009.pdf

Milli Eğitim Bakanlığı (2020). Ĕ̆itim analiz ve değerlendirme raporları serisi.

Odabaşı, F. (1998). Açıköğretim fakültesi ilköğretim öğretmenliğgi lisans tamamlama programı. Bilgisayar destekli eğitim, 135-149. Eskişehir: Anadolu Üniversitesi Yayınları.

Oğuzkan, A. F. (1974). Ĕ̆itim terimleri sözlüğ̈̈. ANKARA: Türk Dil Kurumu Yayınları.

Öner, G. (2017). Sosyal bilgiler ve tarih dersleri için alternatif bir kaynak: eba.gov.tr. Uluslararası Türk Eğitim Bilimleri Dergisi, 5(9), 227-257.

Özbey, A. \& Koparan, T. (2019). EBA ile desteklenen öğrenme ortamının ortaokul öğrencilerinin matematik dersi başarılarına etkisi. 3. Uluslararası Bilim ve Eğitim Kongresi. 21-24 Mart, 2019, Afyonkarahisar.

Özkan, A. \& Deniz, D. (2014). Orta öğretimde görev yapan öğretmenlerin fatih projesine ilişkin görüşleri. Ege Ĕ̆itim Dergisi, 15(1), 161-172.

Öztürk, F. Z. \& Aksoy, H. (2014). Temel eğitimden ortaöğretime geçiş modelinin 8. sınıf öğrenci görüşlerine göre değerlendirilmesi (Ordu ili örneği). On dokuz Mayıs Üniversitesi Eğitim Fakültesi Dergisi, 33(2), 439-454.

Pamuk, S. (2013). Öğretmen ve öğrenci bakış açısıyla tablet pc ve etkileşimli tahta kullanımı: Fatih projesi değerlendirilmesi. Kuram ve Uygulamada Eğitim Bilimleri, 13(3), 1799-1822.

Renshaw, C. E. \& Taylor, H. A. (2000). The educational effectiveness of computer-based instruction. Computers and Geosciences, 26(6), 677-682.

Salman, Ş. (2013). Fatih projesi kapsamında yer alan öğretmen ve öğrencilerin projeden beklentileri ve bilişim teknolojileri kullanımına karşı algıları üzerine bir araştırma: (Yayınlanmamış yüksek lisans tezi). Gazi Üniversitesi Eğitim Bilimleri Enstitüsü, Ankara.

Şahin, M. \& Erman, E. (2019). Tarih dersi öğretmenlerinin eğitim bilişim ağı'na (eba) ilişkin görüşlerinin değerlendirilmesi. Mehmet Akif Ersoy Üniversitesi Ĕ̆itim Fakültesi Dergisi, 49, 256-275.

Şimşek, N. (1998). Öğretim amaçlı bilgisayar yazllımlarının değerlendirilmesi. Ankara: Siyasal Kitabevi.

Talim ve Terbiye Kurulu Başkanlığı [TTKB]. (2015). Müfredatta yenileme ve değişiklik çabalarımız üzerine. https://ttkb.meb.gov.tr/meb iys dosyalar/2017 07/18160003 basin acikla masi-program.pdf

Tekin, M. (2019). EBA destekli oran-orantı öğretiminin ders başarılarına ve üstbilişsel davramıs algılarına etkisi (Yayımlanmamış yüksek lisans tezi). Zonguldak Bülent Ecevit Üniversitesi, Fen Bilimleri Enstitüsü, Zonguldak.

Tomal, N. \& Gül, G. (2018). Coğrafya öğretmenlerinin coğrafya öğretimi ile ilgili medya okuryazarlık düzeyleri. Gazi Ĕ̆itim Bilimleri Dergisi, 4(1), 21-31. 
Tutar, M. (2015). Eğitim bilişim ağı (Eba) sitesine yönelik olarak öğretmenlerin görüşlerinin değerlendirilmesi (Yayımlanmamış yüksek lisans tezi). Karadeniz Teknik Üniversitesi Eğitim Bilimleri Enstitüsü, Trabzon.

Türker, A. \& Güven, C. (2016). Lise öğretmenlerinin eğitim bilişim ağı (EBA) projesinden yararlanma düzeyleri ve proje ile ilgili görüşleri. Ĕ̆itim ve Öğretim Araştırmaları Dergisi, 5(1), 244-254.

Tüysüz, C. \& Çümen, V. (2016). EBA ders web sitesine ilişkin ortaokul öğrencilerinin görüşleri. Uşak Üniversitesi Sosyal Bilimler Dergisi, 9(3), 278-296.

Uluçay, İ.S. \& Çakır, H. (2014). İnteraktif oyunların matematik öğretiminde kullanılması üzerine araştırmaların incelenmesi. Eğitim Teknolojisi Kuram ve Uygulama, 4(1), 13-34.

Ümre, M,M. (2010). Seviye belirleme stnavları (SBS) sosyal bilgiler sorularmın sosyal bilgiler programına ve bilişsel alan basamaklarına göre değerlendirilmesi (Yayınlanmamış yüksek lisans tezi). Gaziosmanpaşa Üniversitesi Sosyal Bilimler Enstitüsü. Tokat.

Vahit, H. R. (2019). EBA etkinlikleriyle yapılan matematik öğretimin başarıya ve tutuma etkisi (Yayımlanmamış yüksek lisans tezi). Kastamonu Üniversitesi, Fen Bilimleri Enstitüsü, Kastamonu.

Varol, N. (2002). Bilişim teknolojilerinin eğitim kurumlarında kullanımları ve eğitimcilerin rolü. Akademik Bilişim Konferansı, 6-8 Şubat, Selçuk Üniversitesi, Konya, Türkiye.

Yakar, L. (2011). Illköğretim ikinci kademe öğrencilerinin SBS puanları ile akademik başarı puanları değişimlerinin izlenmesi ve SBS puanlarının kestirilmesi (Yayınlanmamış yüksek lisans tezi). Abant İzzet Baysal Üniversitesi Eğitim Bilimleri Enstitüsü. Bolu

Yerli, M. S. (2018). Sosyal bilgiler öğretiminde eğitim bilişim ağı (eba) uygulamasının öğrencilerin akademik başarısına etkisi (Yüksek lisans tezi). Adıyaman Üniversitesi, İlköğretim Anabilim Dalı, Adıyaman.

Yıldırım, A. \& Şimşek, H. (2008). Sosyal bilimlerde nitel araştırma yöntemleri. Ankara: Seçkin Yayıncılık. 